\title{
The role of transdisciplinary research in the transformation of food systems
}

\author{
Gerald Schwarz ${ }^{1 *}$, Francesco Vanni ${ }^{2}$ and David Miller ${ }^{3}$
}

\section{${ }^{*}$ Correspondence:}

gerald.schwarz@thuenen.de

${ }^{1}$ Thuenen Institute of Farm

Economics, Bundesallee

63, 38116 Braunschweig,

Germany

Full list of author information is available at the end of the article
Over time, prevailing food systems have led to the depletion of resources and to negative environmental impacts (Rockström et al. 2020). The excessive use of agro-chemicals, heavy machinery, water, and the increasing reliance on fossil fuels in general have contributed to destabilizing the ecosystem processes which are the basis of agricultural production. Intensification and greater homogeneity of agro-ecosystems has led to an increasing dependence on external inputs.

Food systems are responsible for one-third of anthropogenic greenhouse gas emissions, and are shaped by multidimensional and increasingly asymmetric power relations. The concentration of land and power in the hands of large business enterprises can lead to small-scale food producers abandoning agriculture. A radical transformation is needed in farm practices and in human diets to avoid the exhaustion of ecosystems services (Brunori et al. 2020). However, such transformations should be just to all actors in the value chain, from those providing the inputs to the production process, through to the consumer.

The concept of a "just transition" (achieving environmental sustainability along with decent work, social inclusion and poverty eradication) is gaining traction in international policy discourses. It is a significant concept in relation to the aim of the EU Green Deal of achieving climate neutrality by 2050, and in the EU Long-term Vision for the EU's Rural Areas, which highlights the "need for ensuring rights and responsibilities of all actors in just transitions" to sustainable food systems. Research should play a central role in accompanying this radical transformation, by explaining to policy-makers and citizens the reasons for more sustainable, balanced, and fair food systems, the barriers to them being achieved, and where and what risks arise for communities of interest and of place. Research should be supported and guided by well-functioning AKISs, which are central in structuring knowledge exchange, fostering innovation, and will be important in supporting transformative changes of food systems.

In the design and facilitation of just transitions of food systems, the interests and values of different types of actors, power imbalances, and the scale dynamics of transformation processes all need to be taken into account. To identify and understand such requirements for a just transition, a transdisciplinary approach is increasingly advocated and supported by funders, end users of research, and scientists working author(s) and the source, provide a link to the Creative Commons licence, and indicate if changes were made. The images or other third party material in this article are included in the article's Creative Commons licence, unless indicated otherwise in a credit line to the material. If material is not included in the article's Creative Commons licence and your intended use is not permitted by statutory regulation or exceeds the permitted use, you will need to obtain permission directly from the copyright holder. To view a copy of this licence, visit http:// creativecommons.org/licenses/by/4.0/. 
in food systems. Such an approach has been identified as particularly fruitful for investigating complex, 'wicked' problems, in 'real world' settings, such as those under consideration in transformations of food systems to ones which are sustainable and operate within planetary boundaries.

Significant examples of the 'real world' dimension of transdisciplinary research for a 'just transition' to sustainable food systems are those related to open innovation mechanisms (e.g., agroecosystem living labs or communities of practice on food systems) that are promoting co-learning in a science-policy-society dialogue on planning, decision-making and implementation of the strategies necessary for food systems transformation. An aim of such mechanisms is to enable improvements in the governance capacity of local actors, and contextualize data and information within a place-based approach.

Participatory transdisciplinary research on transitions of food systems should stimulate reflexive learning about the relevant plurality of underlying values, perspectives, assumptions, and institutional and power structures. Competences need to be developed to enable researchers and practitioners take on the roles of different types of actors (e.g., change agent, intermediary, knowledge broker, and capacity builder) (Den Boer et al. 2021). The commitment of financial resources should encourage and facilitate novel insights into different and new roles of actors in transdisciplinary approaches.

Individual research projects are unlikely to have the resources and outreach to create the conditions to scale-up the transformation processes. However, investments in transdisciplinary research programmes or platforms offer prospects of positively impacting upon the direction of research that can transform farming and food systems at EU and national levels. Key initiatives are the Horizon Europe Mission on 'A Soil Deal for Europe: 100 living labs and lighthouses to lead the transition toward healthy soils', and the candidate Horizon Europe Partnerships on Agroecology and Food Systems. Each can create and strengthen long-term relationships and networks of multi-stakeholder interactions, conceptualizations of pathways of just transitions of food systems (Mitter et al. 2020), and instruments for their delivery.

Although research in agriculture and food sciences is increasingly oriented toward stronger levels of interaction and integration across disciplines, and across the science-society divide, the complexities involved in this collaborative, multi-party, and transdisciplinary approach remain challenging for researchers and practitioners.

Three key areas of reflection are proposed for transdisciplinary research into the transformation of food systems:

- combining transdisciplinary and conventional disciplinary research to increase understanding of the economic, ecological, and social processes required to transform food systems within different levels of governance;

- addressing challenges of marginalization and inequality of places and people across Europe by facilitating fair access for all actors to engage in, and benefit from, research and innovation, to enable the transformation of food systems;

- linking research on food system transformation with capacity building, education and citizen focused co-learning. 
Enhanced collaboration across different scientific disciplines and stakeholder engagement, in combination with the adoption of a more systematic approach, has the potential to increase the impact of agricultural and food economics (Fresco et al. 2021). However, several key requirements should be considered in this context.

Analysis of the economics of farming and food systems is required to understand the costs and benefits of processes of just transitions, combined with participatory methods for the co-construction of specific place-based strategies. Institutional analysis is essential for the identification of all driving forces such as regulations, property rights, power relations, market organization, information technology infrastructures, cultures and traditions. The overall objective is not only to improve the understanding of the structure of food systems, but also to co-design effective solutions at relevant levels of food system governance. Complementing the institutional analysis, further analysis is needed of the effectiveness of policies, strategies and their contexts, and how their implementation can be promoted through measures on the ground. The audience for the findings of such analysis is that of policymakers with remits to encourage transformations of food systems to achieve aims of sustainability. Finally, there is a need for foresight exercises and scenario-building to inform and facilitate the science-policy-society dialogue on the co-benefits and trade-offs, risks, and opportunities associated with transformations in food systems.

Advancing processes of transdisciplinary research into these key requirements from agricultural and food economics can make substantial impacts on the transformations of food systems which is needed to inform and achieve targets and objectives of public policy in the EU and further afield.

Authors' contributions

All authors read and approved the final manuscript.

\section{Declarations}

Competing interests

The authors declare that they have no competing interests.

Author details

${ }^{1}$ Thuenen Institute of Farm Economics, Bundesallee 63, 38116 Braunschweig, Germany. ${ }^{2}$ Council for Agricultural Research and Economics (CREA) - Research Centre for Agricultural Policies and Bioeconomy, via Po 14, 00198 Rome, Italy.

${ }^{3}$ The James Hutton Institute, Aberdeen AB15 8QH, UK.

Published online: 16 December 2021

\footnotetext{
References

Brunori G, Branca G, Cembalo L, D'Haese M, Dries L (2020) Agricultural and Food Economics: the challenge of sustainability. Agric Food Econ 8:12. https://doi.org/10.1186/s40100-020-00156-2

Den Boer ACL, Broerse JEW, Regeer BJ (2021) The need for capacity building to accelerate food system transformation. Curr Opin Food Sci 42:119-126. https://doi.org/10.1016/j.cofs.2021.05.009

Fresco LO, Geerling-Eiff F, Hoes AC, van Wassenaer L, Poppe KJ, van der Vorst JG (2021) Sustainable food systems: do agricultural economists have a role? Eur Rev Agric Econ 48(4):694-718. https://doi.org/10.1093/erae/jbab026

Mitter H, Techen AK, Sinabell F, Helming K, Schmid E, Bodirsky B, Holman I, Kok K, Lehtonen H, Leip A, Le Mouël C, Mathiis E, Mehdi B, Mittenzwei K, Mora O, Østad K, Øygarden L, Priess JA, Reidsma P, Schaldach R, Schönhart M (2020) Shared socio-economic pathways for European agriculture and food systems: the Eur-agri-SSPs. Glob Environ Change. https:// doi.org/10.1016/j.gloenvcha.2020.102159

Rockström J, Edenhofer O, Gaertner J, DeClerck F (2020) Planet-proofing the global food system. Nat Food 1:3-5. https://doi. org/10.1038/s43016-019-0010-4
} 


\section{Publisher's Note}

Springer Nature remains neutral with regard to jurisdictional claims in published maps and institutional affiliations.

Submit your manuscript to a SpringerOpen ${ }^{\circ}$ journal and benefit from:

- Convenient online submission

- Rigorous peer review

- Open access: articles freely available online

- High visibility within the field

- Retaining the copyright to your article

Submit your next manuscript at $\boldsymbol{\nabla}$ springeropen.com 